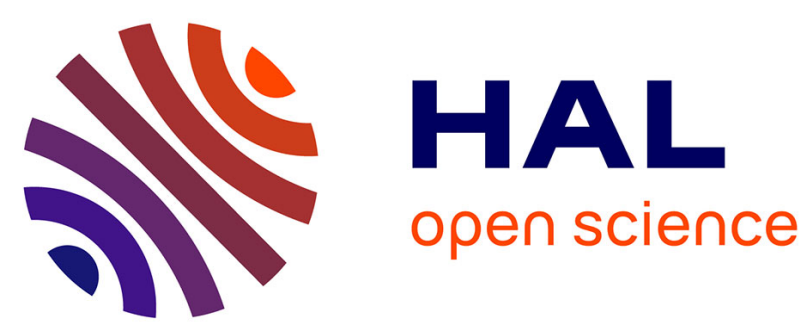

\title{
Interfacial reactivity in aluminium/carbon fibre composites
}

S. Mercier, P. Ehrburger, J. Lahaye

\section{To cite this version:}

S. Mercier, P. Ehrburger, J. Lahaye. Interfacial reactivity in aluminium/carbon fibre composites. Journal de Physique IV Proceedings, 1993, 03 (C7), pp.C7-1723-C7-1726. 10.1051/jp4:19937270 . jpa-00251911

\section{HAL Id: jpa-00251911 https://hal.science/jpa-00251911}

Submitted on 1 Jan 1993

HAL is a multi-disciplinary open access archive for the deposit and dissemination of scientific research documents, whether they are published or not. The documents may come from teaching and research institutions in France or abroad, or from public or private research centers.
L'archive ouverte pluridisciplinaire HAL, est destinée au dépôt et à la diffusion de documents scientifiques de niveau recherche, publiés ou non, émanant des établissements d'enseignement et de recherche français ou étrangers, des laboratoires publics ou privés. 


\title{
Interfacial reactivity in aluminium/carbon fibre composites
}

\author{
S. MERCIER, P. EHRBURGER and J. LAHAYE*
}

Centre de Recherches sur la Physico-Chimie des Surfaces Solides, 24 av. du Président Kennedy, 68200 Mulhouse, France

*Université de Haute-Alsace, 2 rue des Frères Lumière, 68200 Mulhouse, France

\begin{abstract}
The study of the interfacial reactions between carbon fibres and aluminium has been performed using a mass spectrometer. Analysis of the gaseous species evolved by the fibres during heat treatment show that interfacial reactions occur between some of these gases and aluminium. The products of these reactions are aluminium carbide and aluminium oxides. The aluminium carbide produced during heat treatment has been quantitatively measured by determining the amount of methane produced upon the hydrolysis of the carbide.
\end{abstract}

Key words : carbon fibres, interfacial reactions, metal matrix composites

\section{Introduction}

Interfacial reactions in a carbon fibre/metallic matrix composite is a major limiting factor in the development of such materials. Reactions between the fibres and the metal during the manufacture of the composites can lead to matrix embrittlement, fibre degradation and appearance of interfacial brittle phases [1]. These phenomena produce materials of poor mechanical properties and which are susceptible to corrosion [2]. The understanding of the interfacial reactivity is thus essential for the optimisation of fibre/metal pairs and the manufacturing techniques. This paper presents the results of the study of the interfacial reactivity between carbon fibres (M40) and pure aluminium. Analysis of the gases evolved by the fibres during heat treatments showed that reactions between some of the gases and aluminium occur in addition to the reaction between the carbon of the fibres and aluminium.

\section{Gas-aluminium interactions}

\section{Experimental procedure}

Woven carbon fibres were coated with aluminium by physical vapour deposition (PVD) under vacuum. The purity of the aluminium was $99,99 \%$ and the thickness of the deposits was $100 \mathrm{~nm}$ and $200 \mathrm{~nm}$. The samples were then heat treated in a furnace 
connected to a mass spectrometer in order to follow the gas emissions both qualitatively and quantitatively.

\section{Results and discussion}

During the different heat treatments of the carbon fibres, the following gases are evolved : $\mathrm{H}_{2}, \mathrm{H}_{2} \mathrm{O}, \mathrm{N}_{2}, \mathrm{CO}, \mathrm{CO}_{2}$. In the presence of aluminium and at temperatures higher than $600^{\circ} \mathrm{C}$, the amounts of $\mathrm{H}_{2} \mathrm{O}, \mathrm{CO}$ and $\mathrm{CO}_{2}$ decrease. Figure 1 shows the emission of $\mathrm{CO}$ during continuous pumping of the gaseous species evolved from different samples. The more the fibres are covered with aluminium, the less $\mathrm{CO}$ is released. In order to verify that the decrease in the emission of $\mathrm{CO}$ is due to reactions between aluminium and gases, and not to gases trapped in the aluminium coating, a given pressure of $\mathrm{CO}$ was introduced in the reactor and maintained in contact with a woven fibres coated with aluminium (Figure 2). At temperatures higher than $650^{\circ} \mathrm{C}$, the decrease in the pressure of the $\mathrm{CO}$ introduced in the reactor points out the reactivity between aluminium and $\mathrm{CO}$. The reactions with $\mathrm{CO}$ and $\mathrm{CO}_{2}$ are assumed to be the following :

$$
\begin{aligned}
& 6 \mathrm{Al}+3 \mathrm{CO} \rightarrow \mathrm{Al}_{4} \mathrm{C}_{3}+\mathrm{Al}_{2} \mathrm{O}_{3} \\
& 8 \mathrm{Al}+3 \mathrm{CO}_{2} \rightarrow \mathrm{Al}_{4} \mathrm{C}_{3}+2 \mathrm{Al}_{2} \mathrm{O}_{3}
\end{aligned}
$$

As the gases are continuously evacuated out of the reactor, reactions (1) and (2) can happen only at the fibre/metal interface.

However, the main reaction in the carbon/aluminium system is the reaction between the carbon of the fibres and aluminium:

$$
4 \mathrm{Al}+3 \mathrm{C} \rightarrow \mathrm{Al}_{4} \mathrm{C}_{3} \quad(3)
$$

$\mathrm{Al}_{2} \mathrm{O}_{3}$ produced by reactions (1) and (2) can not be distinguished from $\mathrm{Al}_{2} \mathrm{O}_{3}$ already present in the aluminium coating which was partially oxidised during the PVD and during the lengh of time the samples were left in air. $\mathrm{Al}_{4} \mathrm{C}_{3}$ is produced simultaneously by reactions (1), (2) and (3). The contribution of reactions (1) and (2) to the formation of $\mathrm{Al}_{4} \mathrm{C}_{3}$ can therefore be estimated by the decrease of $\mathrm{CO}$ and $\mathrm{CO}_{2}$ emissions when aluminium is coated on the fibres. An estimation of the amount of $\mathrm{Al}_{4} \mathrm{C}_{3}$ formed by reaction (3) can then be made on measuring the total amount of $\mathrm{Al}_{4} \mathrm{C}_{3}$ formed by all three reactions.

In fact, due to the extremely low amounts of $\mathrm{CO}$ and $\mathrm{CO}_{2}$ released by the fibres during heat treatment, the amount of aluminium carbide produced by the ensuing reactions is much lower than the amount of carbide produced by reaction (3). For example, after a rise in temperature from $500^{\circ} \mathrm{C}$ to $640^{\circ} \mathrm{C}$ at a rate of $5^{\circ} \mathrm{C} / \mathrm{min}$. and after a $30 \mathrm{~min}$. period at a steady temperature of $640^{\circ} \mathrm{C}$, the amount of $\mathrm{Al}_{4} \mathrm{C}_{3}$ produced by reactions (1) and (2) did not exceed $1,3 \%$ of the total amount of $\mathrm{Al}_{4} \mathrm{C}_{3}$.

\section{Study of the solid species formed during heat treatments}

Experimental procedure

Woven carbon fibres coated under vacuum with aluminium were heat treated in order 
to form aluminium carbide and put in contact with water vapour at $300^{\circ} \mathrm{C}$. In contact with water vapour, aluminium carbide decomposes to release methane. Using mass spectrometry and a volumetric method, the amount of methane was quantitatively detected.

\section{Results and discussion}

The decomposition of $\mathrm{Al}_{4} \mathrm{C}_{3}$ to $\mathrm{CH}_{4}$ is slow and reaches a maximum after a few hours (Figure 3). Using hydrolysis, $\mathrm{CH}_{4}$ was detected only at temperatures above $600^{\circ} \mathrm{C}$ (the samples were held at the specific temperature during 30 minutes). It was found that the amount of aluminium carbide depends not only on the heat treatment, but also on the length of time the samples were exposed to air between the PVD coating and the heat treatment (Figure 4). The decrease in the amount of $\mathrm{Al}_{4} \mathrm{C}_{3}$ detected with increasing time spans in air can be attributed to the oxidation of aluminium. The oxides formed in air could not react with carbon to form $\mathrm{Al}_{4} \mathrm{C}_{3}$.

Knowing exactly the amount of aluminium coated on the woven fibres, it is possible to calculate the percentage of $\mathrm{Al}_{4} \mathrm{C}_{3}$ produced, assuming that $100 \% \mathrm{Al}_{4} \mathrm{C}_{3}$ would be obtained if all the aluminium had reacted with the fibres to produce carbide. The maximum amount of carbide formed during heat treatments at $700^{\circ} \mathrm{C}$ and above is $61 \%$ after a period of 4 hours in air. The remainder is due to the aluminium oxides formed during the PVD and the period of time the samples were in air. Figure 5 is a profile of the aluminium coating made by XPS on a carbon substrate, showing that metallic aluminium accounts for about $63 \%$ of the total deposit.

\section{Conclusion}

1. The formation of aluminium carbide at the interface is due not only to the reaction between the carbon of the fibres and aluminium, but also to the reactions between the gases, evolved by the fibres during heat treatment, and aluminium.

2. The study of the hydrolysis of woven carbon fibres coated with aluminium allowed a comparison of the formation of $\mathrm{Al}_{4} \mathrm{C}_{3}$ for different heat treatments and for different fibres.

\section{References}

[1] MORTENSEN A., CORNIE J.A., FLEMING M.C., Journal of Metals 40 (1988) 12

[2] HUGHES A.E., HEDGES M.M., SEXTON B.A., J. of Mater. Sci. 25 (1990) 4856-4865

[3] KOSOLAPOVA T.Ya., Carbides, Plenum Press (1971) 41 


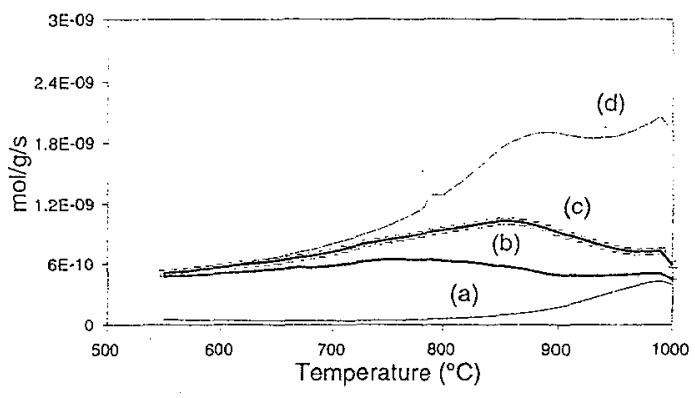

(a) system without sample

(b) woven carbon fibres metallised on both sides

(c) woven carbon fibres metallised on one side

(d) woven carbon fibres

Figure 1: Thermodesorption of CO for different samples

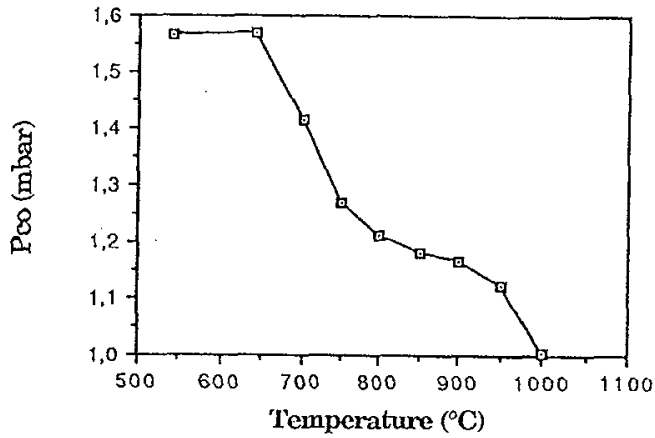

Figure 2: Evolution of the pressure of CO introduced

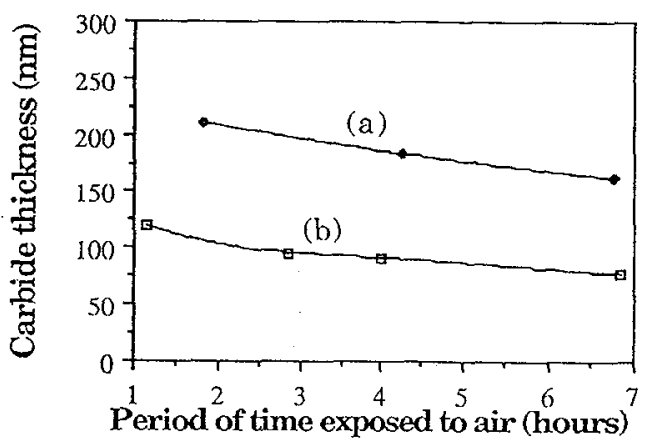

Figure 4: Dependance of the Al4C3 thickness with the length of time the samples were in air for heat treatments of $30 \mathrm{~min}$ at $700^{\circ} \mathrm{C} \mathrm{(a)} \mathrm{and} 640^{\circ} \mathrm{C} \mathrm{(b)}$

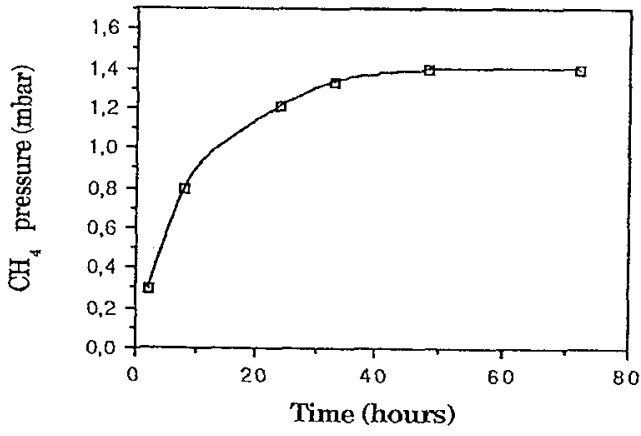

Figure $3: \mathrm{CH}_{4}$ emission

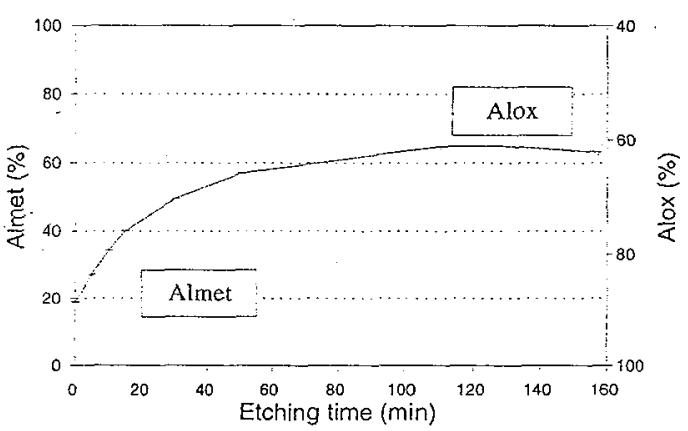

Figure 5 : XPS profile of the aluminium coating for metallic aluminium and oxidised aluminium 